\title{
A Cross-Sectional Study of Aggression among School Adolescents in Karnataka, India
}

\author{
Sneha Kumari ${ }^{1}$, Jugal Kishore ${ }^{2}$, RK Mandal ${ }^{3}$
}

\begin{abstract}
Introduction: Adolescents are placed in critical stage of human development when they are stepping from childhood to adulthood. Worldwide, it is seen that aggression is one of the most common features in this group.
\end{abstract}

Aims and Objectives: (1) To identify aggression among school-going adolescents and (2) To assess different sociodemographic characteristics associated with aggression among these students

Methodology: A cross-sectional descriptive study was conducted in one of the private schools in Karnataka from $1^{\text {st }}$ September to $1^{\text {st }}$ December, 2015 (3 months). Study population comprised of high school children studying in classes VIII-X. A pre-tested, semi-structured, self-administered questionnaire was distributed to the study subjects. For assessing aggression, a modified version of direct and indirect aggression scale (DIAS) was used. School authority permitted the study. An information sheet and consent form was given to each student. The consent form was to be signed by a parent or guardian and returned to the school. Data was entered in MS-Excel. Data was analyzed by using frequency tables and significant association was established by chi-square test.

Results: A total of 187 students participated in the present study. A significant proportion of adolescents scored very high on aggression scale. Males were found to be more aggressive than females and as the age of school children advanced, aggression scores also increased. And these results were statistically significant $(p<0.05)$.

Conclusion: Overall, prevalence of aggression was high in adolescents, especially among males, late adolescents and Hindus and whose mothers were less educated. Understanding sex and age differences in the development of various types of aggressions during adolescence can guide the development of violence prevention programs. Such intervention programs should be started early in life to have the most impact on aggression during adolescence.

Keywords: Aggression, Adolescents, Students

\section{Introduction}

With globalization of the world, aggression has become an important feature of adolescents. Aggression is a behavior aimed at causing physical or psychological pain to any living being. Aggressive personality is at increased risk for

${ }^{1}$ Senior Resident, ${ }^{2}$ Director Professor \& Head, VMMC \& Safdarjung Hospital, New Delhi.

${ }^{3}$ Principal, BGS World School, Karnataka.

Correspondence: Dr. Sneha Kumari, VMMC \& Safdarjung Hospital, New Delhi.

E-mail Id: sneharanjan811@gmail.com

Orcid Id: https://orcid.org/0000-0003-2876-8997

How to cite this article: Kumari S, Kishore J, Mandal RK. A Cross-Sectional Study of Aggression among School Adolescents in Karnataka, India. Ind J Youth Adol Health 2017; 4(4): 4-9.

Digital Object Identifier (DOI): https://doi.org/10.24321/2349.2880.201728

ISSN: 2349-2880 
depression, anxiety, social withdrawal, low self-esteem and stress. As we know about $21 \%$ of Indian population are adolescents (about 243 million), ${ }^{1}$ they are the future of the nation, forming a major demographic and economic force. They have specific needs which vary with gender, life circumstances and socioeconomic conditions. At this crucial stage of life, aggressive personality can lead to social avoidance and stress in life.

Aggression is considered as a behavior between members of the same species that is intended to cause humiliation, pain or harm. Ferguson and Beaver defined aggressive behavior as "Behavior which is intended to increase the social dominance of the organism relative to the dominance position of other organisms". ${ }^{2}$ The aggressive personality results from the coloring of the individual's total personality by frequently unorganized aggressive impulses. Aggression may be of direct or indirect type. Direct aggression may be physical or verbal. Physical aggression includes hitting, punching, pushing, slapping, kicking, etc. On the other hand, verbal aggression means abuse, spreading of rumor, malign, etc. Any aggressive behavior that is carried out via another person is considered as indirect aggression. Many theories regarding aggression have been postulated. According to some scientists, ${ }^{3,4}$ this behavior is largely related to learning from social environment. Another hypothesis suggests association of this behavior with frustration which may occur after being prevented from reaching a goal. ${ }^{5}$

In daily life situations, it is observed that adolescents are deviating from commonly accepted social and constitutional norms, showing aggressive behavior in most of the situations. Since there is paucity of studies conducted in India to describe the trajectories of social aggression during adolescence for either males or females, there is little evidence to suggest specific differences in boys' and girls' developmental trajectories of social aggression during adolescence. Therefore, keeping these objectives in mind, we have conducted a cross-sectional study among schoolgoing adolescents to identify aggression among school-going adolescents and to find out different sociodemographic characteristics associated with aggression among these students.

\section{Materials and Methods}

\section{Study Area and Study Population}

It was a school-based, cross-sectional descriptive study. This school was situated in the rural area of Karnataka. It was a private school from $1^{\text {st }}$ to $10^{\text {th }}$ class. Students from rural as well as urban area were coming to attend the school. Study population comprised of high school children studying in classes VIII-X.

\section{Sample Size and Study Duration}

This study was conducted from $1^{\text {st }}$ September to $1^{\text {st }}$ December, 2015 (3 months). A total of 187 students participated in the present study. Permission was sought from the principal of the school to recruit students for the study. The questionnaire was distributed to the students in their classrooms during a pre-arranged time. Each student who had returned a consent form was given a copy of the questionnaire for completion. Every effort was made to ensure that the students had privacy while completing the questionnaire.

\section{Study Parameters and Study Tool}

Data was collected regarding the sociodemographic variables like age, sex, religion, type of family, education of parents and working status of mothers of adolescents. A pre-designed, pre-tested, semi-structured, selfadministered questionnaire was used for data collection. Apart from collecting sociodemographic information, a modified version of direct and indirect aggression scale (DIAS) was used for data collection. The DIAS questionnaire was developed by Björkqvist et al. ${ }^{6}$

\section{Statistical Analysis}

Data was entered in MS-Excel. Data was analyzed by using frequency tables and significant association was established by chi-square test taking $p$ value $<0.05$.

\section{Results}

A total of 187 students participated in the present study. 
Table 1.Beliefs Supporting Aggression of Study Participants ( $N=187$ )

\begin{tabular}{|c|c|c|c|c|c|c|}
\hline S. No. & Statements & Strongly Agree & Agree & Neither & Disagree & Strongly Disagree \\
\hline i & $\begin{array}{c}\text { It makes you feel big and } \\
\text { tough when you push } \\
\text { someone around. }\end{array}$ & $28(15 \%)$ & $52(27.8 \%)$ & $13(6 \%)$ & $52(27.8 \%)$ & $42(22.5 \%)$ \\
\hline ii & $\begin{array}{c}\text { If you back down from a } \\
\text { fight, everyone will think } \\
\text { you are a coward }\end{array}$ & $23(12.3 \%)$ & $24(12.8 \%)$ & $26(13.9 \%)$ & $65(34.8 \%)$ & $49(26.2 \%)$ \\
\hline iii & $\begin{array}{c}\text { Sometimes you have only } \\
\text { two choices-get punched } \\
\text { or punch the other kid first }\end{array}$ & $20(10.7 \%)$ & $40(21.4 \%)$ & $46(24.6 \%)$ & $35(18.7 \%)$ & $46(24.6 \%)$ \\
\hline iv & $\begin{array}{c}\text { It's ok to hit someone } \\
\text { if you just go crazy with } \\
\text { anger }\end{array}$ & $13(6.9 \%)$ & $35(18.7 \%)$ & $16(8.6 \%)$ & $74(39.6 \%)$ & $49(26.2 \%)$ \\
\hline v & $\begin{array}{c}\text { A guy who doesn't fight } \\
\text { back when other kids } \\
\text { push him around will lose } \\
\text { respect }\end{array}$ & $22(11.8 \%)$ & $22(11.8 \%)$ & $15(8 \%)$ & $75(40.1 \%)$ & $53(28.3 \%)$ \\
\hline vi & $\begin{array}{c}\text { A guy shows he really likes } \\
\text { his friend if he gets in fights } \\
\text { with other guys about him }\end{array}$ & $40(21.4 \%)$ & $38(20.3 \%)$ & $21(11.2 \%)$ & $43(23 \%)$ & $45(24 \%)$ \\
\hline
\end{tabular}

Table 1 reveals that nearly $43 \%$ students felt big and tough when they pushed someone around. Nearly $26 \%$ of students agreed that if they backed down from a fight then everyone would think that he/she was a coward. About 32\% of students were in favor of having two choices only in a critical situation, i.e., get punched or punch the other kid first. About $25 \%$ of students agreed that it was ok to hit someone if they were just crazy with anger. Nearly $23 \%$ of students understood that a guy who did not fight back when other kids pushed him around would lose respect. Nearly half (41\%) of the students were of the opinion that a person virtually shows the liking about his friend if he gets in fights with other guys about him.

Table 2.Modified Direct and Indirect Aggression Scale (DIAS): For Each Question, Indicate How Many Times You Did It during Last 7 Days ( $\mathrm{N}=187$ )

\begin{tabular}{|c|c|c|c|c|}
\hline S. No. & Statements & 0 & $1-3$ & 4 and above \\
\hline i. & I teased students to make them angry. & $60(32 \%)$ & $90(48.1 \%)$ & $37(19.8 \%)$ \\
\hline ii & I got angry very easily with someone & $30(16 \%)$ & $115(61.5 \%)$ & $42(22.5 \%)$ \\
\hline iii & I fought back when someone hit me first & $65(34.8 \%)$ & $92(49.1 \%)$ & $48(25.6 \%)$ \\
\hline iv & I said things about other kids to make other students laugh & $48(25.7 \%)$ & $91(48.7 \%)$ & $48(25.7 \%)$ \\
\hline v & I encouraged other students to fight & $148(79.1 \%)$ & $26(13.9 \%)$ & $13(7 \%)$ \\
\hline vi & I pushed or shoved other students & $124(66.3 \%)$ & $48(25.7 \%)$ & $25(13.4 \%)$ \\
\hline vii & I was angry most of the day & $42(22.5 \%)$ & $120(64.2 \%)$ & $25(13.4 \%)$ \\
\hline viii & I got into a physical fight because I was angry & $92(49.2 \%)$ & $103(55.1 \%)$ & $18(9.6 \%)$ \\
\hline ix & I slapped or kicked someone & $116(62 \%)$ & $56(30 \%)$ & $15(8 \%)$ \\
\hline $\mathrm{x}$ & I called other students bad names & $119(63.6 \%)$ & $53(28.3 \%)$ & $15(8 \%)$ \\
\hline$x i$ & I threatened to hurt or to hit someone. & $117(62.6 \%)$ & $51(27.3 \%)$ & $19(10.2 \%)$ \\
\hline
\end{tabular}

We find from Table 2 that $68 \%$ of study subjects used to tease other students to make them angry of which $19.8 \%$ did it for more than four times in a week. Majority (84\%) of them got angry easily with someone of which $11.6 \%$ subjects did it for more than six times. About $65 \%$ subjects fought back when hit first, of which $16.6 \%$ did it for more than six times. Among study subjects, $74.3 \%$ used to tell things about other kids to make other students laugh. Most (79.1\%) of them had not encouraged other students to fight. Nearly $34 \%$ of them pushed/shoved other students. Many (77.5\%) of them got angry most of the day. Nearly $50 \%$ students got into a physical fight in anger and $38 \%$ of subjects slapped or kicked someone. Nearly $36 \%$ participants called other students by bad names and $37 \%$ students threatened to hurt or to hit someone. 
Table 3.Association of Aggression Scale with Various Sociodemographic Parameters ( $N=187)$

\begin{tabular}{|c|c|c|c|c|c|}
\hline \multirow[t]{2}{*}{ Variable } & \multirow[t]{2}{*}{ Number (\%) } & \multicolumn{3}{|c|}{ Aggression Scale } & \multirow{2}{*}{$\begin{array}{c}\text { Chi-square, } \\
\text { p value }\end{array}$} \\
\hline & & $0 \mathrm{n}(\%)$ & $1-3 \mathrm{n}(\%)$ & 4 and above $n(\%)$ & \\
\hline \multicolumn{6}{|c|}{ Sex } \\
\hline Male & $104(55.6)$ & $20(19.2)$ & 55 (52.9) & $29(27.9)$ & \multirow{2}{*}{$\begin{array}{c}20.9 \\
0.00002 *\end{array}$} \\
\hline Female & $83(44.4)$ & $40(48.2)$ & $35(42.2)$ & $8(9.6)$ & \\
\hline \multicolumn{6}{|c|}{ Age group } \\
\hline $12-14$ & $139(74.3)$ & $46(33.1)$ & $71(51.1)$ & $22(15.8)$ & \multirow{2}{*}{$\begin{array}{c}12.4 \\
0.002 *\end{array}$} \\
\hline $15-17$ & $48(25.7)$ & $14(29.2)$ & $15(31.3)$ & $19(39.6)$ & \\
\hline \multicolumn{6}{|c|}{ Residence } \\
\hline Rural & $90(48.1)$ & $29(32.2)$ & $43(47.8)$ & $18(20)$ & \multirow{2}{*}{$\begin{array}{l}0.009, \\
0.995\end{array}$} \\
\hline Urban & $97(51.9)$ & $31(31.9)$ & $47(48.5)$ & $19(19.6)$ & \\
\hline \multicolumn{6}{|c|}{ Type of family } \\
\hline Nuclear & $151(80.7)$ & $52(34.4)$ & $73(48.3)$ & $26(17.2)$ & \multirow{2}{*}{$\begin{array}{l}3.97 \\
0.137\end{array}$} \\
\hline Joint & $36(19.3)$ & $8(22.2)$ & $17(47.2)$ & $11(30.6)$ & \\
\hline \multicolumn{6}{|c|}{ Religion } \\
\hline Hindu & $171(91.4)$ & $53(31)$ & $83(48.5)$ & $35(20.5)$ & \multirow{2}{*}{$\begin{array}{l}1.281 \\
0.527\end{array}$} \\
\hline Others & $16(8.6)$ & $7(43.8)$ & $7(43.8)$ & $2(12.5)$ & \\
\hline
\end{tabular}

*Statistically significant ( $p$ value $<0.05)$

Table 3 reveals that $55.6 \%$ were males and $44.4 \%$ were females. It was found that males were having more scores on aggression scale than girls and it was also statistically significant $(p<0.05)$. It shows males were more aggressive than females. Most (74.3\%) of them were in $12-14$ years age group followed by $15-17$ years $(25.7 \%)$. Its association with age reflected that as the age advances, aggression also increases among study participants $(p<0.05)$. Regarding the area of residence, $51.9 \%$ study subjects belonged to urban area while $48.1 \%$ were of rural area. Though there was no significant associations between residence and aggression scale, majority belonged to nuclear families $(80.7 \%)$ and were Hindus (91.4\%). But the type of family and religion did not influence scores on aggression scale. But it was found that $30.6 \%$ participants from joint families were very aggressive as they scored more than four on aggression scale.

Table 4.Association of Aggression Scale with Education of Parents and Occupation of Mother ( $N=187$ )

\begin{tabular}{|c|c|c|c|c|c|}
\hline \multirow[t]{2}{*}{ Variable } & \multirow{2}{*}{$\begin{array}{c}\text { Number } \\
(\%)\end{array}$} & \multicolumn{3}{|c|}{ Aggression Scale } & \multirow{2}{*}{$\begin{array}{c}\text { Chi-square, } \\
\text { p value }\end{array}$} \\
\hline & & $0 \mathrm{n}(\%)$ & $1-3 \mathrm{n}(\%)$ & 4 and above $n(\%)$ & \\
\hline \multicolumn{6}{|c|}{ Education of father } \\
\hline Higher degree (more than matriculation) & $111(59.4)$ & $33(29.7)$ & $59(53.2)$ & $19(17.1)$ & \multirow{3}{*}{$\begin{array}{l}4.84 \\
0.303\end{array}$} \\
\hline Up to high school pass $\left(10^{\text {th }}\right)$ & $60(32.1)$ & $19(31.7)$ & $26(43.3)$ & $15(25)$ & \\
\hline Illiterate & $16(8.6)$ & $8(50)$ & $5(31.3)$ & $3(18.8)$ & \\
\hline \multicolumn{6}{|c|}{ Education of mother } \\
\hline Higher degree (more than matriculation) & $85(45.5)$ & $33(38.8)$ & $47(55.3)$ & $13(7)$ & \multirow{3}{*}{$\begin{array}{l}11.306 \\
0.023^{*}\end{array}$} \\
\hline Up to high school pass $\left(10^{\text {th }}\right)$ & $82(43.9)$ & $15(18.3)$ & $41(50)$ & $26(31.7)$ & \\
\hline Illiterate & $20(10.7)$ & $5(25)$ & $7(35)$ & $8(40)$ & \\
\hline \multicolumn{6}{|c|}{ Occupation of mother } \\
\hline Working & $55(29.4)$ & $20(36.4)$ & $26(47.3)$ & $9(16.4)$ & \multirow{2}{*}{$\begin{array}{l}4.84 \\
0.303\end{array}$} \\
\hline Non-working/housewives & $132(70.6)$ & $40(30.3)$ & $64(48.5)$ & $28(21.2)$ & \\
\hline
\end{tabular}

Table 4 reflects that most of the fathers (59.4\%) were having higher degree, but only $29.7 \%$ students got 0 score on aggression scale. There was no statistically significant association. On the other hand, mother's education was significantly associated with aggression. It means that as the mother's education increases, aggression among children decreases. Maximum number of mothers (70.6\%) who were non-working/housewives, higher scores of aggression were found in their children.

\section{Discussion}

Adolescence is the critical stage of anyone's life and there are enormous changes in the psychological, physical and social domains of life. Aggression is a common phenomenon in this period of life, particularly in the later part. In the present study, beliefs supporting aggression among study participants revealed that nearly $43 \%$ of students felt big and tough when they pushed someone around. Nearly 
$26 \%$ of students agreed that if they backed down from a fight then everyone would think that he/she was a coward. About $32 \%$ of students were in favor of having two choices only in a critical situation, i.e., get punched or punch the other kid first. About $25 \%$ of students agreed that it was ok to hit someone if they just got crazy with anger. Nearly $23 \%$ of students understood that a guy who does not fight back when other kids push him around would lose respect. Nearly half (41\%) of the students were of the opinion that a guy showed his liking for his friend if he got into fights with other guys about him. Therefore, it was found that nearly one-third of the adolescents were having beliefs supporting aggression. WHO estimate shows that up to $20 \%$ adolescents have one or more mental or behavioral problems. ${ }^{7}$ Studies conducted in different parts of the world show that prevalence of behavioral and emotional problems in adolescents range from $16.5 \%$ to $40.8 \%$ and in India it is in the range of $13.7 \%$ to $50 \%{ }^{8-10}$ As adolescents form one fifth of India's population, this means a sizable disease burden on the society. ${ }^{11}$

By using modified direct and indirect aggression scale (DIAS), it was seen that $68 \%$ of study subjects used to tease other students to make them angry. Majority (84\%) of them got angry easily with someone. About $65 \%$ of the subjects fought back when hit first. Among study subjects, 74.3\% used to tell things about other kids to make other students laugh. Most (79.1\%) of them had not encouraged other students to fight. Nearly $34 \%$ of them pushed/shoved other students. Many (77.5\%) of them got angry most of the day. Nearly $50 \%$ of the students got into a physical fight in anger and $38 \%$ of subjects slapped or kicked someone. Nearly $36 \%$ participants called other students by bad names and $37 \%$ students threatened to hurt or to hit someone. This reveals that most of the adolescents sored higher on aggression scale. General aggression tends to begin at certain critical periods of life. Aggression may make its appearance in adolescence, the period when a young human being is struggling with many adjustment problems. Aggression as a potential outcome of psychosocio-cultural settings appears to be a very important aspect of personality. As aggressors always remain at high risk due to their risky life styles that may lead to development of behavioral problems, delinquency, substance or chemical dependence and other medical conditions such as cardiovascular problems, cancer, and brain damage.

It was found that $55.6 \%$ of males and $44.4 \%$ of females were showing aggressive tendencies. It was found that males were having more scores on aggression scale than girls and it was also statistically significant $(p<0.05)$. It shows males were more aggressive than females. Various studies also proved that there is a strong relation of testosterone with aggression, ${ }^{12-15}$ which may be the reason for more aggressive behavior among males. Results of a metaanalysis also revealed that males are more aggressive than females. Concentration of testosterone most clearly correlated with aggressive responses involving provocation. A similar study conducted in Guwahati revealed that males were found to be significantly more physically aggressive than females $(p=0.001) .{ }^{16}$

The findings of the present study reflected that most (74.3\%) of students were in 12-14 years age group followed by $15-17$ years $(25.7 \%)$. Its association with age reflected that as the age advanced, aggression also increased among study participants $(p<0.05)$. It was contradictory to the findings in West Bengal's study where physical aggression score was significantly higher in younger adolescents (15-17 years) than among $18-19$ years $(p<0.001)$. It may be due to high expectation from family, academic performance, peer pressure and sudden biological changes in the body among late adolescents. As a result, they are unable to cope with the changed circumstances so, they experience sadness and depression. Depression often gives rise to aggressive behavior in them. Moyer (1976) identified eight types of aggression, of which irritable aggression indicates the relation of aggression with frustration, deprivation and stressful situation. According to frustration aggression hypothesis, ${ }^{17}$ the motivation for aggression increases when the ongoing behavior is interrupted or when an individual is prevented from reaching a goal leading to frustration. On the other hand, the peer effect on older adolescents is higher than the younger one. According to social learning theory of aggression by Bandura, human aggression is largely learnt by watching other people behave aggressively, either in person or in films. ${ }^{3}$

Majority of the aggressive adolescents belonged to nuclear families (80.7\%) and were Hindus (91.4\%). But it was found that $30.6 \%$ of the participants from joint families were very aggressive as they scored more than four on aggression scale. Though the present study did not find association of aggression with type of family and area of residence, it shows that there is widespread distribution of aggression irrespective of type of family and area of residence. Regarding educational status of parents, when most of the fathers (59.4\%) were having higher degree, still only $29.7 \%$ students got 0 score on aggression scale. There was no statistically significant association. On the other hand, mother's education was significantly associated with aggression. It means that as the mother's education increases, aggression among children decreases. Educated mothers could guide the adolescents about the proper way to tackle changing life circumstances. It was found that when the maximum number of mothers $(70.6 \%)$ was non-working/housewives their children got higher scores on aggression scale. It reflects that they engaged in their household duties so much that they could not have enough time to pay attention to these adolescents. Similar was the finding in West Bengal's study ${ }^{18}$ where there was no significant difference of physical aggression scores among 
different religions, different castes, and types of the families as well as working status of mothers.

\section{Conclusion}

Overall, prevalence of aggression was high in adolescents especially among males, late adolescents and Hindu adolescents whose mothers were less educated. Modified direct and indirect aggression scale (DIAS) seems to be an effective tool for assessing aggression. Thus, understanding sex differences and age differences in the development of various types of aggression during adolescence can guide the development of violence-prevention programs. Such intervention programs targeting male late adolescents should be started earlier in life to have the most impact on aggression during adolescence and preventive strategy for older adolescents. In these initiatives, parents, especially mothers, play an important role to provide care and support to adolescents. Expanding the targeted behaviors and the audiences for prevention initiatives will help to make healthy adolescents in the present and responsible adult in the future.

\section{Acknowledgments}

The authors would like to thank the students, teachers, supporting staff of BGS World School, Chickballapur, Karnataka, Dr. Dileepan, Dr. Manila, and Dr. Suruchi who are postgraduate students of Department of Community Medicine Vardhman Mahavir Medical College, New Delhi, for their kind support.

\section{Conflict of Interest: None}

\section{References}

1. Strategy Handbook. Rashtriya Kishor Swasthya Karyakram. Adolescent Health Division, Ministry of Health and Family Welfare, Government of India. January 2014. Available from: https://www.dropbox. com/s/0oj4p422y7st4ku/RKSK\%20Strategy\%20 Handbook.pdf.

2. Ferguson CJ, Beaver KM. Natural born killers: The genetic origins of extreme violence. aggression and violent behavior. 2009; 14(5): 286-94.

3. Bandura A. Aggression: A social learning analysis. Englewood Cliffs, NJ: Prentice-Hall 1973.

4. Henry PS, Charles CM. Social learning theory. Journal of Organizational Behavior Management 1982; 3(4): 55-63.

5. Berkowitz L. Frustration-aggression hypothesis: Examination and reformulation. Psychological Bulletin
1989; 106(1): 59-73.

6. Björkqvist K, Lagerspetz KMJ, Österman K. Direct and Indirect Aggression Scales (DIAS). Finland: ÅboAkademi University 1992.

7. The World Health Report 2001. Mental health: New understanding, new hope. Geneva: World Health Organization 2001; 39-44.

8. Robert ER, Attkinson C, Rosenblatt A. Prevalence of psychopathology among children and adolescents. Am J Psychiatry 1998; 155(6): 715-24.

9. Jenson PS, Watanabe HK, Richters JE et al. Prevalence of mental disorder in military children and adolescents: Finding from a two stage community survey. J Am Acad Child Adolesc Psychiatry 1995; 34: 1514-24.

10. Mishra A, Sharma AK. A clinico-social study of psychiatric disorders in 12-18 years school going girls in urban Delhi. Indian J Community Med. 2001; 26(2): 71-75.

11. Belfer ML, Sharma AK. Child and adolescent mental health around the world: Challenges for progress. J Indian Assoc. Child Adolesc. Ment. Health. 2005; 1: 31-36.

12. Terburg D, Morgan B, van Honk J. The testosteronecortisol ratio: A hormonal marker for proneness to social aggression. Int J Law Psychiatry 2009 Jul-Aug; 32(4): 216-23.

13. Hermans EJ, Ramsey NF, van Honk J. Exogenous testosterone enhances responsiveness to social threat in the neural circuitry of social aggression in humans. Biol Psychiatry 2008 Feb 1; 63(3): 263-70.

14. Mehta PH, Beer J. Neural mechanisms of the testosterone aggression relation: the role of orbitofrontal cortex. $J$ Cogn Neurosci. 2010 Oct; 22(10): 2357-68.

15. Kreuz LE, Rose RM. Assessment of aggressive behavior and plasma testosterone in a young criminal population. Psychosom Med. 1972 Jul-Aug; 34(4): 321-32.

16. Talukdar RR, Deka RS. A Study on aggression level among adolescents. International Journal of Social Science and Humanities Research Oct-Dec 2014; 2(4): 91-94.

17. Berkowitz L. Frustration-aggression hypothesis: Examination and reformulation. Psychological Bulletin 1989; 106(1): 59-73.

18. Datta PP, Firdoush KA. Association of aggression with sociodemographic characteristics: A cross sectional study among rural adolescents. National Journal of Medical Research Oct-Dec 2012; 2(4).

Date of Submission: 2017-10-21 Date of Acceptance: 2017-11-22 